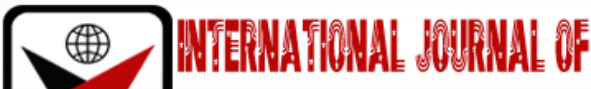

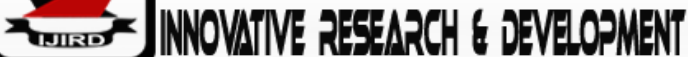

ISSN 2278-0211 (Online)

\section{Age and Job Satisfaction among Public Secondary School Teachers in Nakuru County, Kenya}

\begin{tabular}{|c|}
\hline Margaret Wangari Maina \\
Ph.D. Student, Department of Educational Management, \\
Laikipia University, Kenya \\
John Kanjogu Kiumi \\
Associate Professor, Department of Curriculum and Educational Management, \\
Laikipia University, Kenya \\
Dr. Peter Githae \\
Senior Lecturer, Department of Curriculum and Educational Management \\
Laikipia University, Kenya
\end{tabular}

\begin{abstract}
:
Teacher job satisfaction has in the recent past raised concerns among researchers and practitioners in Kenya. This concern has been occasioned by industrial disharmony in the teaching profession by way of teachers' strikes including dissatisfaction related behaviours among teachers such as absenteeism and desertion of duty. This is what informed the study whose core objective was to investigate the level of job satisfaction among secondary school teachers in Nakuru County-Kenya and the extent to which age differences existed in job satisfaction among the teachers. Data were collected through a self-delivered questionnaire from 341 teachers who were randomly selected from 3,092 teachers in the county. The instrument was validated through a pilot study while its internal and external reliability was estimated through Cronbach's alpha ( $r=.945)$ and split-half $(r=.905)$ techniques. Collected data was analyzed usingANOVA statistic. The study revealed that job satisfaction increased with teachers' age and that the age-job satisfaction gap was statistically significant $(p=.000)$. The findings also demonstrated that the significant job satisfaction differences were between teachers below 30 years of age and their 30 years and above counterparts. Drawing on these findings, it is imperative for the national teacher management entity, specifically the Teachers Service Commission (TSC) to borrow a leaf from the recommendations of this study with a view to enhancing job satisfaction among the newly recruited teachers. Similarly, secondary schools Boards of Management (BoMs) need to implement these recommendations in their schools so as to improve job satisfaction among newly posted teachers in their schools. This will undoubtedly enhance their performance to the benefit of the students.
\end{abstract}

Keywords: Teachers, job satisfaction, age, Nakuru County, Kenya

\section{Introduction}

Job satisfaction and motivation are very crucial to the long-term growth of any educational system around the world. As Ololube (2006) points out, job satisfaction is important in the same way as professional knowledge, teaching skills, and access to educational resources. This, as Patrick (2007) points out, is due to the strong link between job satisfaction and academic achievement of students. A satisfied teacher has a friendly attitude and greater enthusiasm which contributes immensely towards the educational advancement of the students, whereas a dissatisfied teacher has an irritable and hostile attitude thereby causing great harm to the institution as well as to the society (Sankar\&Vasudha, 2015). A study carried out by Akomolafe, Ogunmakin and Fasooto (2014) in Nigeria emphasized that the consequences of job dissatisfaction among teachers are absenteeism from schools, high turnover, aggressive behaviour towards colleagues and learners, early exit from the teaching profession and psychological withdrawal from work. Otto and Arnold (2005) have linked teacher turn over or the motivation to leave the teaching profession to dissatisfaction with various aspects of their job. A higher turnover leads to teacher shortfall, and consequently high student-teacher ratio whose deleterious effect on students' learning gains cannot be overstated.

Job satisfaction of teachers is a function of an individual's needs fulfilment since teachers are not similar in terms of temperament, interests, and experience. Therefore, their needs and consequently levels of job satisfaction may differ (Steers, Porter \&Bigley, 1996). In view of teachers' heterogeneity, Evans (1998) has averred that the best approach in an attempt to study teacher satisfaction is to adopt the individuality dimension, where the focus is on individual characteristics such as age. Research on the age-job satisfaction relationship has yielded mixed results. For instance, Crossman and Harris (2006) identified significant differences in job satisfaction among teachers in different age groups, 
with those in the 22-30 and 41-50 years age categories reporting higher satisfaction levels compared to their colleagues in the 31-40 years age bracket. However, Dehaloo (2011) found that the least motivated teachers were from the age categories 27-39 years (with approximately 6 to 15 years of experience), and 40-54 years (with 16 to 25 years of experience). Findings of a study conducted among teachers in Finland also revealed that there was a strong positive relationship between teachers' age and job satisfaction (Rasku\&Kinnunen, 2003). This observation is consistent with the study by Bennell and Akyeampong (2007) which found out that young Tanzanian teachers were less satisfied with their job compared to their older counterparts. Akiri and Ugborugbo (2009) have observed that as one gets older, the less likely one is to quit the job. The two writers have observed that as workers get older, they have fewer alternative job opportunities and hence they are less likely to resign because the longer tenure tends to provide them with higher wage rates, longer paid vacations and benefits that are more attractive. However, the two researchers have pointed out that it is not at all times that older teachers experience higher level of job satisfaction. For instance, as teachers get close to the retirement age some tend to look forward to the retirement date hence becoming less satisfied. However, other studies (George et al., 2008; Otube, 2004) found that age had no significant influence on teachers' job satisfaction.

\section{Literature Review}

Several studies (For instance Abiodun \& Gbadebo, 2012; Bashir, 2011; Fitzmaurice, 2012;Mengistu, 2012; Tadesse \& Muriithi, 2017) have investigated whether different-aged teachers differ in their level of job satisfaction. However, majority of the studies have found that job satisfaction increases with increase in age. For instance, a study by Abiodun and Gbadebo (2012) revealed that there was a significant positive relationship between age and job satisfaction ( $r=0.312$ ) which implied that job satisfaction of the participants increased with increase in age.The implication is that age was a significant determinant of job satisfaction among the teachers. The finding was consistent with findings of other studies by Fitzmaurice (2012), Bashir (2011) and Milan (2019). The foregoing view could be due to the high expectations for young employees which are adjusted as employees grow older. In addition, older teachers have adapted to the working conditions prevailing in their schools, thus raising their level of job satisfaction (Mengistu, 2012).

In contrast, other studies did not establish any significant differences in job satisfaction levels among different aged teachers. For instance, a study by Crossman and Harris (2006) in the United Kingdom did not report any difference in levels of job satisfaction among different aged groups of teachers. Similarly, studies by Otube (2004) and Otanga and Mange (2014) revealed that age did not have a significant influence on job satisfaction. Since the foregoing studies have presented inconsistent findings on the age-job satisfaction relationship, the present study was conducted with a view to finding out whether its findings will shed more light in regard to age-job satisfaction discourse.

\section{Theoretical Framework}

The study was guided by Job Characteristics theory and Herzberg's Two Factor theory. Herzberg (1958) postulates that there are two set of factors in the work place that influence the level of satisfaction of employees namely; hygiene factors and motivators or growth factors. Hygiene factors are job context factors concerned with a good working environment and which meet lower order needs of workers including supervisory practice, working conditions, status and job security. Motivators on the other hand are intrinsic factors that relate with the job itself and meet higher order needs including achievement, recognition and opportunities for growth and advancement. Thus, the two set of factors are separate and distinct since they are concerned with two different set of needs. Inferring from the theory, teacher motivation is accomplished by focusing on the motivators. In other words, the teaching job must enhance a feeling of achievement and status. Moreover, teachers must be recognized by their supervisors for goal achievement and opportunities for growth.

Hackman and Oldham (1976) have averred that there are five job characteristics that determine the level of employee satisfaction namely; skill variety, task identity, task significance, autonomy and feedback. Job characteristics theory holds that the five job characteristics lead to three critical psychological states which in turn influence individual and work outcomes such as job satisfaction, absenteeism, work motivation among others. Drawing on the theory, teacher job satisfaction can be enhanced in three ways. First, the teaching job needs to be enriched so that teachers experience meaningfulness in their work, by giving them the opportunity to practice their skills and involving them fully in the overall development of learners. Second, teachers should experience responsibility in their work by offering them a chance to work independently with minimum supervision. Third, teachers need to be given feedback of performance by their supervisors on a continuous basis.

\subsection{Conceptual Framework}

The study was grounded in the reasoning that age of the teacher (independent variable) is a reliable predictor of job satisfaction (dependent variable). Furthermore, the study conjectured that the effect of age on job satisfaction may be moderated by extraneous variables such as longevity in a school, position held by the teacher in a school and teaching workload. The perceived interplay between the three categories of variables is shown schematically in figure 1. 


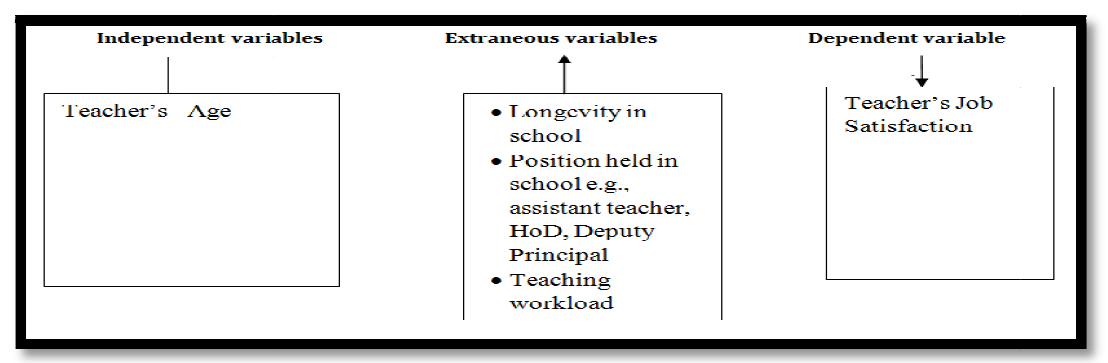

Figure 1: Hypothesized Relationship among Variables Subsumed in the Study

Maczyk, DeMatteo and Festinger (2005) have observed that extraneous variables are capable of generating rival/competing hypothesis that might explain the results of a study thereby compounding its external validity. For this reason, there is need to control extraneous variables in order to minimize their effects on the dependent variable. This was done by randomly selecting teachers in the study area. This ensured that all teachers irrespective of their background participated in the study.

\section{Methodology}

The study adopted ex-post facto research design. This design is utilized in a scenario whereby the independent and dependent variables have already interacted. Consequently, it is not possible to manipulate the independent variable(s) so as to determine its/their effect on the dependent variable(s). In this regard, the effect of the interaction between the independent and dependent variables is determined retrospectively (Mugenda\&Mugenda, 2003). The design was deemed suitable in light of the fact that the study aimed at determining retrospectively the extent to which age may be influencing job satisfaction among public secondary school teachers in Nakuru County.

\section{Instrumentation}

A self-administered questionnaire was used to collect data. The questionnaire was personally delivered to the 341 public secondary school teachers in the study area who were selected by simple random and proportionate sampling techniques from a total population of 3,092 teachers. Selection of the 341 subjects was guided by Krejcie and Morgan (1970) table for determining sample sizes from given populations. The questionnaire had 61 Likert scale items with response categories ranging from 'highly satisfied', 'satisfied', 'slightly satisfied', 'dissatisfied' and 'very dissatisfied' which were allocated '5', '4', '3', '2' and '1' scores respectively. Therefore, a high mean score indicated a high level of satisfaction while a low mean score showed a low level of satisfaction.

\subsection{Validity and Reliability of the Instrument}

The instrument was validated by thirty randomly selected teachers from the neighbouring Nyandarua County. The teachers were requested to assess the extent to which items in the instrument were adequately representing facets of satisfaction with their career. Based on the observations proffered by the 30 teachers, changes which were deemed necessary were affected in the instrument before it was administered to the actual study participants. The instrument's external reliability on the other hand was estimated through split half technique. After administering the instrument to the pilot group, it was split into two halves in which one set comprised the even numbered items while the other set consisted of the odd numbered items. Scores generated from the two halves for each respondent were then computed separately and correlated, where a correlation coefficient of $r=.905$ was realized. Further, internal reliability which is a measure of the degree to which the instrument is measuring a single idea (in this case job satisfaction) was estimated using Cronbach's alpha. The alpha obtained was .945 (94.5\%) which implied that the items in the instrument were measuring teachers' job satisfaction $94.5 \%$ of the time and that the error may have occurred only $5.5 \%$ of the time. The two estimates of reliability indicated that the instrument's reliability was high (Marczyket al., 2005)

\section{Results and Discussion}

Data from the 61 Likert scale items on job satisfaction was analyzed through computation of job satisfaction mean scores for different aged teachers which were in turn compared with a view to establishing whether they were significantly different. The computed mean scores are tabulated in table 1.

\begin{tabular}{|c|c|c|c|c|c|c|}
\hline Age & N & Mean & Std. Deviation & Std. Error & \multicolumn{2}{|c|}{ 95\% Confidence Interval for Mean } \\
\cline { 5 - 7 } & & & & & Lower Bound & Upper Bound \\
\hline Below 30 & 98 & 2.7041 & .61274 & .06190 & 2.5812 & 2.8269 \\
\hline $30-35$ & 78 & 3.7692 & .42405 & .04801 & 3.6736 & 3.8648 \\
\hline $36-40$ & 49 & 4.0000 & .00000 & .00000 & 4.0000 & 4.0000 \\
\hline $41-45$ & 35 & 4.0000 & .00000 & .00000 & 4.0000 & 4.0000 \\
\hline $46-50$ & 27 & 4.0000 & .00000 & .00000 & 4.0000 & 4.0000 \\
\hline Above 50 & 33 & 4.4545 & .50565 & .08802 & 4.2752 & 4.6338 \\
\hline Total & 320 & 3.5938 & .75365 & .04213 & 3.5109 & 3.6766 \\
\hline
\end{tabular}

Table 1: Teachers' Job Satisfaction Mean Scores by Age

Source: Field data, 2020 
Evaluation of the data in table 3 shows that job satisfaction scores increased with increase in teachers' age. This job satisfaction trend appears to suggest that an increase in teachers' age has a positive effect on job satisfaction. This finding is consistent with the results of a previous study by Fitzmaurice (2012) in Ireland which revealed that job satisfaction increased with age, with those aged 18-25 years posting a lower mean in regard to how well the jobs which were performing gave them those things which they viewed as important to them than those in the 46-65 years age bracket. Similarly, Bennel and Akyeampong (2007) found that young Tanzanian teachers were less satisfied with their job than their older counterparts. Other studies (for instance, Kemuntoetal., 2018; Milan, 2019) established that age had a significant difference with job satisfaction. Milan pointed out that the difference was probably due to presence of different aspirations, expectations, fulfillment, achievement and self-esteem among different age groups of the respondents. However, a study by Kwanghoet al. (2013) in Korea and that of Otanga and Mange (2014) in Kenya reported that age had no significant influence on job satisfaction.

The mean scores were in turn subjected to one-way ANOVA with a view to determining whether they were significantly different or not. The objective of this analysis was to confirm the truth of the assertion proposed by the hypothesis which was stated as follows:

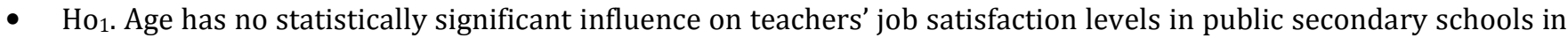
Nakuru County, Kenya. The results of the ANOVA test are summarized in table 2.

\begin{tabular}{|c|c|c|c|c|c|}
\hline Source of Variance & Sum of Squares & df & Mean Square & F & Sig. \\
\hline Between Groups & 122.741 & 5 & 24.548 & 131.884 & .000 \\
\hline Within Groups & 58.446 & 314 & .186 & & \\
\hline Total & 181.188 & 319 & & & \\
\hline
\end{tabular}

Table 2: ANOVA Summary on Teachers' Job Satisfaction by Age

Source: Field data, 2020

An examination of the data shown in table 2 shows that the computed $F$-value $(F=131.884 ; \mathrm{df}=319 ; \mathrm{P}=.000)$ was statistically significant at $\alpha=.05$. In this regard, the hypothesis was rejected and conclusion made that job satisfaction and teachers' age were not statistically independent. Put differently, age had a statistically significant influence on teachers' job satisfaction. However, in order to determine the groups of teachers whose job satisfaction scores were significantly different, Tukey's post hoc test was carried out. The results of Tukey's test are presented in table 3.

\begin{tabular}{|c|c|c|c|c|c|c|c|}
\hline & \multirow{2}{*}{$\begin{array}{l}\text { (I) Age of the } \\
\text { Respondent }\end{array}$} & \multirow{2}{*}{$\begin{array}{l}\text { (J) Age of the } \\
\text { Respondent }\end{array}$} & \multirow{2}{*}{$\begin{array}{c}\text { Mean Difference } \\
(I-J)\end{array}$} & \multirow{2}{*}{$\begin{array}{l}\text { Std. } \\
\text { Error }\end{array}$} & \multirow[t]{2}{*}{ Sig. } & \multicolumn{2}{|c|}{ 95\% Confidence Interval } \\
\hline & & & & & & $\begin{array}{l}\text { Lower } \\
\text { Bound }\end{array}$ & $\begin{array}{l}\text { Upper } \\
\text { Bound }\end{array}$ \\
\hline \multirow{30}{*}{$\begin{array}{l}\text { Tukey } \\
\text { HSD }\end{array}$} & \multirow[t]{5}{*}{ Below 30} & $30-35$ & $-1.06515^{*}$ & .06547 & .000 & -1.2529 & -.8774 \\
\hline & & $36-40$ & $-1.29592^{*}$ & .07549 & .000 & -1.5124 & -1.0795 \\
\hline & & $41-45$ & $-1.29592^{*}$ & .08496 & .000 & -1.5395 & -1.0523 \\
\hline & & $46-50$ & $-1.29592^{*}$ & .09377 & .000 & -1.5648 & -1.0270 \\
\hline & & Above 50 & $-1.75046^{*}$ & .08683 & .000 & -1.9994 & -1.5015 \\
\hline & \multirow[t]{5}{*}{$30-35$} & Below 30 & $1.06515^{*}$ & .06547 & .000 & .8774 & 1.2529 \\
\hline & & $36-40$ & $-.23077^{*}$ & .07864 & .041 & -.4563 & -.0053 \\
\hline & & $41-45$ & -.23077 & .08778 & .093 & -.4825 & .0209 \\
\hline & & $46-50$ & -.23077 & .09633 & .161 & -.5070 & .0455 \\
\hline & & Above 50 & $-.68531^{*}$ & .08959 & .000 & -.9422 & -.4284 \\
\hline & \multirow[t]{5}{*}{$36-40$} & Below 30 & $1.29592^{*}$ & .07549 & .000 & 1.0795 & 1.5124 \\
\hline & & $30-35$ & $.23077^{*}$ & .07864 & .041 & .0053 & .4563 \\
\hline & & $41-45$ & .00000 & .09548 & 1.000 & -.2738 & .2738 \\
\hline & & $46-50$ & .00000 & .10340 & 1.000 & -.2965 & .2965 \\
\hline & & Above 50 & $-.45455^{*}$ & .09716 & .000 & -.7331 & -.1760 \\
\hline & \multirow[t]{5}{*}{$41-45$} & Below 30 & $1.29592^{*}$ & .08496 & .000 & 1.0523 & 1.5395 \\
\hline & & $30-35$ & .23077 & .08778 & .093 & -.0209 & .4825 \\
\hline & & $36-40$ & .00000 & .09548 & 1.000 & -.2738 & .2738 \\
\hline & & $46-50$ & .00000 & .11051 & 1.000 & -.3169 & .3169 \\
\hline & & Above 50 & $-.45455^{*}$ & .10468 & .000 & -.7547 & -.1544 \\
\hline & \multirow[t]{5}{*}{$46-50$} & Below 30 & $1.29592^{*}$ & .09377 & .000 & 1.0270 & 1.5648 \\
\hline & & $30-35$ & .23077 & .09633 & .161 & -.0455 & .5070 \\
\hline & & $36-40$ & .00000 & .10340 & 1.000 & -.2965 & .2965 \\
\hline & & $41-45$ & .00000 & .11051 & 1.000 & -.3169 & .3169 \\
\hline & & Above 50 & $-.45455^{*}$ & .11196 & .001 & -.7756 & -.1335 \\
\hline & \multirow[t]{5}{*}{ Above 50} & Below 30 & $1.75046^{*}$ & .08683 & .000 & 1.5015 & 1.9994 \\
\hline & & $30-35$ & $.68531^{*}$ & .08959 & .000 & .4284 & .9422 \\
\hline & & $36-40$ & $.45455^{*}$ & .09716 & .000 & .1760 & .7331 \\
\hline & & $41-45$ & $.45455^{*}$ & .10468 & .000 & .1544 & .7547 \\
\hline & & $46-50$ & $.45455^{*}$ & .11196 & .001 & .1335 & .7756 \\
\hline
\end{tabular}

Table 3: Results of Tukey's Test on Teachers' Job Satisfaction by Age Source: Field Data, 2020

*. The Mean Difference Is Significant at the 0.05 Level 
Table 3 shows that significant difference $(\mathrm{p}<.05)$ was between teachers who were in the age group below 30 years and teachers in the 30 years and above age groups. Another significant difference was between teachers in the $30-35$ years bracket and those in the 36-40 years age bracket. Further, a statistically significant difference was between teachers in the age group above 50 years and those who were in age groups below 51 years.

\section{Recommendation and Conclusion}

Findings generated by the study have important implications and lessons on how job satisfaction of teachers can be enhanced. For instance, the findings demonstrated that job satisfaction increased with increase in age with younger teachers reporting a lower satisfaction than their older colleagues. On the basis of this observation, the TSC should regularly organize In-service Education and Training (INSET)programmes with a view to identifying the challenges of teachers in different age brackets. In addition, TSC and secondary school Boards of Management (BoMs) need to offer regular induction courses geared towards raising job satisfaction among newly recruited teachers. Additionally, TSC and BoMs need to explore the needs of newly appointed teachers with a view to generating strategies to address them. This will undoubtedly go a long way in raising and sustaining job satisfaction among this category of teachers.

\section{References}

i. Abiodun, M.G. \&Gbadebo, O.A. (2012). Effect of age and work experience on job satisfaction of primary school teachers: Implications for career counselling. International Journal of Asian Social Science, 2(3), 302-309.

ii. Akiri, A. \&Ugborugbo, N. (2009). Analytic examination of teachers' career satisfaction in public secondary schools. Student Home Communication Science, 3 (1), 51-56.

iii. Akomolafe, J. M., Ogunmakin, A.O.\&Fasooto, G.M. (2014). Job satisfaction among secondary school teachers: Emotional intelligence, emotional stress and self-efficacy as predictors. Journal of Education and Social Research, 3 (2), 335-349.

iv. Bashir, K. (2011). The role of demographic factors in the relationship between high performance work system and job satisfaction. A Multidimensional Approach. International Journal of Business and Social Science, 2 (18).

v. Bennell, P. \&Akyeampong, K. (2007). Teacher motivation in Sub-Saharan Africa and South Asia. DFID Department of international Development, 71.

vi. Crossman, A. \& Harris, P. (2006). Job Satisfaction of Secondary School Teachers. Educational Management Administration \& Leadership, 34, 29-46.

vii. Dehaloo, G. (2011). The motivation and job satisfaction of secondary school teachers in Kwazulu-Natal: An education management perspective. Unpublished doctoral thesis, University of South Africa.

viii. Evans, L. (1998). Teacher morale, job satisfaction and motivation. London: Paul Chapman Publishing Ltd.

ix. Fitzmaurice, M. (2012). Job satisfaction in Ireland: An investigation into the influence of self-esteem, generalized self-efficacy and effect. Journal of Education and Behavioural Sciences, 8(3), 148-153.

x. George, E., Louw, D. \&Badenhorst, G. (2008). Job satisfaction among urban secondary school teachers in Namimbia. South African Journal of Education, 28, 135-154.

xi. Hackman, J.R. \& Oldham, G.R. (1976). Motivation through the design of work: Test of a theory. Organizational Behaviour and Human Performance, 16, 250-279.

xii. Herzberg, F. (1957). One more time: how do you motivate employees? Harvard Business Review, 46, 53-62.

xiii. Krejcie, R.V.\& Morgan, D. (1970). Determining Sample Size for Research Activities. Educational and Psychological Measurement, 30 (3), 232-256.

xiv. Maczyk, G., Dematteo, D. \&Festinger, D. (2005). Essentials of Research Design and Methodology. New Jersey, John Wiley \& Sons Inc.

xv. Mengistu, G.K. (2012). Job satisfaction of secondary school teachers in Ethiopia. Unpublished Doctoral thesis, University of South Africa.

xvi. Mugenda, M.O. \&Mugenda, A.G. (2003). Research methods in qualitative and quantitative approaches. Nairobi: Acts press.

xvii. Ololube, N. (2006). Teachers' Job Satisfaction and Motivation for School Effectiveness: An Assessment, University of Helsinki.

xviii. Otto, S. J.\& Arnold, M. G. (2005). A study of experienced special education teachers' perceptions of administrative support. College Student Journal, 39 (2), 253-259.

xix. Otube, N.W. (2004). Job Motivation of Teachers Educating Learners with Special Needs in Four Provinces in Kenya. Unpublished doctoral dissertation, University of Hamburg.

xx. Patrick, A. (2007). An Examination of Teacher Workplace Satisfaction and Student Achievement. Unpublished doctoral dissertation, Georgia Southern University.

xxi. Rasku, A. \&Kinnunen, U. (2003). Job Conditions and Wellness among Finnish Upper Secondary School Teachers. Psychology and Health, 18 No. 4, 441-456.

xxii. Steers, R.M., Porter, L.W.\&Bigley, G.A. (1996). Motivation and leadership at work. New York: McGraw- Hill

xxiii. Sankar, V.S. \&Vasudha, P. (2015). Job satisfaction of primary school teachers. Indian Psychological Foundation, $3(2), 45-52$ 